\title{
'Symbolically burying the six million': post-war soap burial in Romania, Bulgaria and Brazil
}

\author{
Joachim Neander independent researcher \\ jneander@interia.pl
}

\begin{abstract}
During the Second World War and its aftermath, the legend was spread that the Germans turned the bodies of Holocaust victims into soap stamped with the initials 'RIF', falsely interpreted as 'made from pure Jewish fat'. In the years following liberation, 'RIF' soap was solemnly buried in cemeteries all over the world and came to symbolise the six million killed in the Shoah, publicly showing the determination of Jewry to never forget the victims. This article will examine the funerals that started in Bulgaria and then attracted several thousand mourners in Brazil and Romania, attended by prominent public personalities and receiving widespread media coverage at home and abroad. In 1990 Yad Vashem laid the 'Jewish soap' legend to rest, and today tombstones over soap graves are falling into decay with new ones avoiding the word 'soap'. 'RIF' soap, however, is alive in the virtual world of the Internet and remains fiercely disputed between 'believers' and 'deniers'.
\end{abstract}

Key words: Jews, soap, burial, Brazil, Romania, Holocaust, RIF

\section{RIF and the 'Jewish soap' legend}

During the Second World War, the legend spread that the Germans boiled down the victims of the Holocaust to soap. ${ }^{1}$ Alleged proof were the letters 'RIF' stamped on all soap bars distributed in Germany and German occupied countries, misread as an abbreviation of Reines Juden-Fett or 'pure Jewish fat'. In reality, RIF denoted Reichsstelle für Industrielle Fettversorgung, an authority that controlled the distribution and processing of fats for industrial purposes in wartime Germany. ${ }^{2}$

The legend originated in the ghettos of occupied Poland just after the beginning of the war as a kind of Jewish gallows humour. Merging with age-old folktales about killers who used the body fat of their victims for soap-making, it developed a life of its own. Passed on from person to person, it quickly spread to the whole of Eastern and Central Europe. At the turn of 1942, nearly everybody in occupied Poland and Russia - Jews and non-Jews alike - knew the legend and many believed in its truth. In the late summer of 1942, it crossed the seas to Great Britain, the United States and Canada. In the following months, prominent 'soap believers' 
such as Rabbi Stephen Wise, head of both the American and the World Jewish Congress, and Soviet Jewish anti-Fascist activist Solomon Mikhoels spread the legend through press conferences and mass rallies which aroused considerable public attention worldwide.

Since the beginning of 1943, making soap from murdered Jews became a stock phrase in Allied anti-German propaganda. When, however, fighting in the European theatre of war was drawing to a close and the liberators overran concentration camp after concentration camp, killing site after killing site, neither in these locations, nor in the millions of captured German documents, was the slightest trace of soap-making from Holocaust victims found.

This fact, however, prevented neither propagandists - especially those in the Soviet Union, its satellites and among Western fellow travelers of Communism - from continuing to use the 'Jewish soap' story in anti-German propaganda, nor did it keep the legend from becoming an integral part of Jewish collective memory. Nothing stopped nor slowed down the spreading of the myth, neither the fact that mainstream Holocaust historians had always expressed doubts as to the veracity of the story, ${ }^{3}$ nor that Yad Vashem, in 1990, unequivocally declared it 'a mere rumor'. ${ }^{4}$ An episode from recent times shows how deeply it has been engraved on the minds of the people, both Jews and non-Jews. In his address given on 24 January 2005 at the 28th Special Session of the General Assembly of the United Nations, Silvan Shalom, then Israeli Deputy Prime Minister and Minister of Foreign Affairs, said in front of the Globe's assembled delegates that the Nazis took 'the proud Jewish citizens of Vienna, Frankfurt, and Vilna, and even Tunisia and Libya' and 'turn[ed] them . . . to soap'. ${ }^{5}$ His statement went passed unchallenged.

'Jewish soap' has hitherto been first and foremost a matter of discussion in Holocaust denier circles, presented as 'a typical Jewish lie' and exploited for the purpose of undermining and discrediting all evidence of the Holocaust with the argument that they who lie about one thing - soap - will also lie about 'other, more fundamental aspects of the Holocaust story', ${ }^{6}$ a logical fallacy par excellence. Professional historians have seldom taken up the issue. The scholarly community regards 'Jewish soap' and similar Holocaust legends as marginal topics. Their study does not pay off in either winning them recognition or obtaining a promotion and may even arouse suspicion of their advocating 'revisionism'. Historians, therefore, have tended to pass over the issue; if they have mentioned it at all, it is restricted to a brief statement or a footnote in their publications. The burial of cakes of 'Jewish soap', in particular, has never been an object of scholarly study. The following paper is intended to close this gap and to encourage further research, integrating the 'Jewish soap' legend and the soap funerals into the framework of the history of Holocaust remembrance and commemoration. ${ }^{7}$

\section{Burying RIF soap: a mitzvah for the Jewish community}

Jewish religious law demands a decent burial for the dead. Tradition has also extended this mitzvah to severed body parts: first, out of respect for all parts of the human body ${ }^{8}$ and, secondly, to avoid a kohen (a priest or a priest's descend- 
ant) unwittingly coming into contact with such an object, which would make him ritually unclean. ${ }^{9}$ RIF soap, believed to have been made from Jewish bodies (or body parts), therefore, had to receive a proper burial. In the autumn of 1946, for instance, Palestine's Chief Ashkenazi Rabbi Yitzhak HaLevi Herzog demanded from Fiorello LaGuardia, then Director-General of UNRRA, the United Nations' Relief and Rehabilitation Administration, that no RIF soap (allegedly 'manufactured from fat rendered from Jewish corpses in crematoriums') be distributed to the inmates of the camps for 'Displaced Persons' run by UNRRA in Europe. Instead, 'all such soap [should] be sent to Palestine for burial'. ${ }^{10}$

How to treat RIF soap has been a serious issue for religious Jews up to the present, as shown by a news item that, at the beginning of 2011, did the rounds of the Jewish press in the United States. Misaskim, a Brooklyn, New York based Orthodox Jewish not-for-profit organisation providing services for the care of the dead and the needs and conveniences of mourners, had received a bar of RIF soap from the relatives of a recently deceased Holocaust survivor. The family asked Misaskim about the appropriate way of proceeding with the soap bar, and whether it needed to be buried. ${ }^{11}$ Startled by the press reports, other owners of RIF soap gave their bars to Misaskim for examination. Ten soap cakes were even sent to Brooklyn from Poland. ${ }^{12}$ It is not known, however, how Misaskim's rabbinical authority, Rabbi Yechezkiel Roth and his Bais Din, decided upon the matter. ${ }^{13}$

Soap burials gave Jewish communities a powerful opportunity to pay public and joint homage to all those who perished in the Holocaust and to fulfil the mitzvot of remembering the dead and mourning over them. It was of paramount importance to all Jews in the immediate aftermath of the war in a period when there was not yet an institutionalised Holocaust remembrance like today. As Hasia Diner has shown in much detail for the United States, from the beginning Jewish communities were fully aware of the historical dimension of the catastrophe (השוֹאָה) befallen on their people. Across all ideological and religious divisions there was a common feeling that the Nazi murder of one third of world Jewry must never be forgotten. ${ }^{14}$

Cemeteries were the right place not only for remembering the victims but also for giving them back to the Jewish community. From an anthropological point of view - and from those who believed in the human origin of the RIF soap - the Nazis had exerted governance over the Jewish bodies beyond the latter's physical death by 'burying' them in cakes of 'Nazi soap'. The re-burial of this soap on the beit olam - that is, on Jewish ground - visibly demonstrated that the Nazis were no longer governing the Jewish dead, but now the Jews themselves. Through performing the traditional Jewish funerary and mourning rites, Jewry could now 'let go the lost object' (in the Freudian sense), integrate it into the chain of ancestors and look ahead towards the future instead of sinking into fruitless melancholy. ${ }^{15}$

A bar of soap on which the murderers (allegedly) had callously written 'Made from Jewish flesh' was ideally suited for symbolising those who would never return, whose mortal remains were scattered across the killing fields of Eastern Europe or had gone with the wind, dissolving into the smoke of the crematoria. RIF soap burial in Palestine and Israel was, in addition, a symbolic aliyah of all those who did not make it in their lifetime. ${ }^{16}$ The early post-war soap burials, therefore, were first 
and foremost symbolic acts in which even the most secular Jews, and those few who did not believe in the human origins of RIF soap, could wholeheartedly participate.

The State of Israel was founded in mid-May 1948. In its constitution there was guaranteed the right of aliyah to every Jew. Until that time, spokesmen of Jewish organisations had seized the opportunity of soap burials to draw the attention of politicians and the media to the plight of Holocaust survivors who were still being held in camps for 'displaced persons' and prevented from leaving Europe by the restrictive immigration laws of their target countries, first and foremost Palestine and the United States.

RIF soap was buried by Jews all over the world, in Europe, Israel, Canada, Cuba, Brazil, the United States and Australia. In the Americas, particularly grandiose monuments were erected above soap graves at the Jewish cemeteries of Guanabacoa near La Habana, Cuba, of Elmont, New York and of Vila Rosali near Rio de Janeiro, Brazil. The Guanabacoa monument is explicitly dedicated to the six million victims of the Holocaust. It is a quadratic column on a three-tiered plinth, topped by a Star of David. The inscription on the lower plinth is in Spanish and reads: 'In this place various soap bars are buried, made from Jewish human fat, part of the six million victims of the Nazi barbarism of the twentieth century'. ${ }^{17}$ The monument, erected above the grave, was ceremoniously unveiled on 16 March 1947 and was most probably the first of its kind in the Americas. ${ }^{18}$ The Elmont monument, a huge obelisk, was dedicated half a year later on 7 September 1947 and is probably the oldest Holocaust memorial in the United States. ${ }^{19}$

\section{Soap burials in Bulgaria and Brazil}

Probably the first documented soap burial took place at Sofia, the capital of Bulgaria, in the late autumn of 1944, more than half a year before the war ended in Europe. Immediately after liberation, the Jewish community had bought some cakes of RIF soap from a Russian soldier. They were tested and found to be 'made from animal fat'. Although it could not be proven that the 'animal' fat was human, the soap was given the benefit of the doubt and buried in a solemn ceremony, which turned into a homage to all Nazi victims. ${ }^{20}$

One of the most spectacular, and also one of the best documented, burials of RIF soap - sixteen bars, brought to Brazil by Holocaust survivors - took place at Vila Rosali, a suburb of Rio de Janeiro, on 12 October 1947. It was attended by five thousand mourners and carried a clear political message: 'Through this symbolic act, the leaders of the [Jewish] community tried to convey to government officials the fact that Brazil should immediately open its doors to other survivors. ${ }^{21}$ The religious ceremonies were performed jointly by three Chief Rabbis: Tzikinowsky, Zingerevitch and Lemle, representing Orthodox, Reform and Progressive Judaism. At the overcrowded Jewish cemetery, men and women were crying and holding one another in grief and sorrow. 'On [this] Sunday morning, each Jew was bearing a piece of his parents, of relatives and friends, a piece of their selves to their graves', recalled Brazilian writer Zevi Ghivelder when describing the event and its meaning in his novel As Seis Pontas da Estrela. ${ }^{22}$ 
The funeral was a big media event, announced at the end of September and covered by regional and nationwide newspapers until the beginning of November. ${ }^{23}$ Undoubtedly the largest readership was reached by $O$ Cruzeiro, ${ }^{24}$ a broadsheet magazine which had, at the time, a circulation of over 700,000 copies. On 1 November 1947 it carried a four-page feature about the soap funeral written by the magazine's chief reporter David Nasser and illustrated with pictures taken by star photographer José Medeiros. ${ }^{25}$ The soap funeral at Vila Rosali also found entry into Brazilian and foreign literature, both scholarly and fictional. It has been mentioned, for example, in a biography of David Nasser, ${ }^{26}$ in an anthology of scholarly articles about Jewish-Brazilian fictional literature ${ }^{27}$ in a study about the tragic fate of the Mediterranean Sephardi Jews ${ }^{28}$ and in a novel about Jewish immigrants to Brazil. ${ }^{29}$

A documentary film - Di Levaye Funem Zeyf Fun Mentshlekhn Fets (The Burial of Soap from Human Fat) - was also shot and screened as a support accompanying Yiddish-language feature films in São Paulo and at the São Carlos cinema in Cinelândia, Rio de Janeiro, in the second half of March $1949 .{ }^{30}$ The film itself seems to have been lost. However, a 2:35 minutes colour clip taken by an amateur filmmaker at the funeral was discovered in Rio de Janeiro in mid-2012 and uploaded onto YouTube. ${ }^{31}$ Although silent it gives a good impression of the immense crowd of attendants and the prevailing atmosphere at the funeral.

On 18 September 1949, the foundation stone of a huge monument was laid over the soap grave 'The Martyrs' Bulwark'. ${ }^{32}$ The event was widely announced and reported in the press, local papers from Rio de Janeiro as well as Nossa Voz-Undzer Shtime from São Paolo, a Yiddish-language weekly with a nationwide circulation and some content in Portuguese. ${ }^{33}$ Every year since then, the Jews from the Federal State of Rio de Janeiro have gathered on Yom Hashoah before the soap grave at the cemetery of Vila Rosali and solemnly commemorated the victims of the Holocaust. Since 2006 the ceremonies have taken place on 27 January, ${ }^{34}$ declared International Holocaust Victims' Remembrance Day by the United Nations in 2005.

\section{Romania: collecting RIF soap for burial}

Romania most probably has more 'Jewish soap' graves than the rest of the world altogether, Israel included. ${ }^{35}$ Though a considerable part of Romanian Jewry perished in the Holocaust, the majority survived. Their leaders convinced the new Communist rulers to issue a nationwide ban on RIF soap, of which a considerable quantity existed in the country at the end of the war. Most of it had been left by the Germans, Romania's allies during the Second World War, during their retreat, ${ }^{36}$ and some had been brought by soldiers who had fought together with (or against) the Germans, and more soap came home with the returnees from the camps.

An article in The American Jewish Outlook from Pittsburgh, Pennsylvania in April 1947 gives a clue as to why there is hardly a Jewish cemetery in Romania without a soap grave, and why at most places the tombstone is at the same time a monument to the victims of Auschwitz or of the Holocaust in general: 


\section{Joachim Neander}

Every cake of this soap represented to the Rumanian Jew a brother or a sister lost in the horrible gas-chambers of the Auschwitz inferno. As soon as the soap began to appear in the shops the Jewish communities launched a campaign to have it bought up. Special funds were allocated for this purpose. The government banned the use of this soap and ordered every locality that had a supply to sell it only to the Jewish community. Thus all known supplies of the R.I.F. soap were collected and buried in Jewish cemeteries. ${ }^{37}$

In Constanța, for example, the Jewish community did not wait for state legislation and took the matter into its own hands. Immediately after the end of the war, 'teams of two people... visited house by house and asked the inhabitants whether they possessed German soap. The soap thus found was collected and turned over to the Jewish community', remembered Andor Andrasi, who organised the search action on behalf of Constanța's Jews in $1945 .^{38}$

As could be expected, many owners of RIF soap did not care much about the ban. Soap was a scarce commodity and, especially for those who were not Jewish, using it for one's own purposes or selling it on the black market seemed to make more sense and was far more profitable than turning it in to the authorities for burial. The citizens, therefore, had to be reminded of their civic duties from time to time. In mid-March 1946, for instance, the Police Department of Braşov made the following announcement in the press:

It is brought to the public's attention that soap is being offered for sale having the letters R.J.F. [sic] stamped on it. The soap comes from the corpses of people killed in Poland by the Hitlerites. The sale, use, and possession of this kind of soap is strictly prohibited. It is, therefore, brought to your attention that those who possess such soap must turn it in at the Police Department, Room \#10, within three days. Violators will be severely punished. ${ }^{39}$

The 'politically correct' use of the word 'people' instead of 'Jews' showed the influence of Soviet 'newspeak' on the Romanian official language: at that time, the word 'Jew' was carefully avoided when speaking of Nazi victims.

\section{Soap burials in the capital and in the province}

In Bucharest, the capital, the first documented soap burial took place on 15 November 1945. A quantity of 1,500 RIF soap bars - 'representing the remains of our families and friends' - was solemnly buried, together with spoilt Torah scrolls and other damaged ritual objects, at the New Jewish Cemetery at Giurgiu Road no. $162 .{ }^{40}$ Although the ceremony was headed by Chief Rabbi Alexander Şafran and many Jewish personalities participated - rabbis, intellectuals and community leaders - the event did not seem to have raised much interest outside the Romanian Jewish community. Apart from a very detailed article in a Jewish periodical ${ }^{41}$, nothing could be found in the newspaper archives. Among the mourners was 'a young man who escaped from Auschwitz' who said that he had been forced to 
make soap there 'with his own hands' ${ }^{42}$ He was, most likely, a former member of the prisoner work detail that recycled soap from the deported Jews' baggage in the Theatergebäude, just outside of the main camp's perimeter. ${ }^{43}$

Soon soap burials became, however, public events of general interest in Romania. Not only did the entire local Jewish community participate in them, individually or in groups from the whole gamut of Jewish associations, but also included representatives of the Churches, the Communist and other (licensed) political parties, volunteer organisations, the Romanian - and sometimes even the Soviet - military and the civilian authorities. ${ }^{44}$ The County Archives of Vrancea, for example, hold a letter of invitation from the Jewish community of Focşani to the prefect of Putna County: ${ }^{45}$

We have the honor of asking you to kindly participate in the funeral ceremony of the burial of the mortal remains, contained in soap bars, of Jews killed in the torture camps of Nazi Germany, which will take place on January 31, 1946 at 2:30 p.m. ${ }^{46}$

The inscription on the tombstone that was erected some time later above the grave explicitly speaks of 'the mortal remains of Jews, killed in Nazi camps and transformed into soap bars'. ${ }^{47}$

A funeral ceremony held at Bucharest on 4 August 1947 attracted international attention far beyond Jewish circles, ${ }^{48}$ and a photograph taken at the event showing weeping women behind a table with soap bars on top made the rounds of the world press. The caption read:

One of the strangest ceremonies ever performed took place in the Jewish cemetery in Bucharest recently when a large quantity of soap was solemnly buried with the full Jewish burial ritual. The soap was symbolic of the thousands of Jews who were murdered by Nazis in 'horror camps' and their bodies rendered down to produce the fats for soap. Here, relatives of murdered Jews mourn over some of the soap used in the ceremony. ${ }^{49}$

The picture even made it into the Australian Outback, appearing on the front page of a provincial newspaper. ${ }^{50}$

For a long period of time, the soap graves at the Jewish cemeteries of Romania remained places of official Holocaust commemorations. In the beginning of June 1969, for instance, ceremonies were held to commemorate the twenty-fifth anniversary of the deportation of the Jews from Transylvania to Auschwitz. The Jewish Telegraphic Agency reported that the ceremony at Oradea was 'attended by representatives of the Rumanian Government and of all Rumanian religious groups', and that '[s]ervices were followed by a pilgrimage to a symbolic grave of the martyrs in the Jewish cemetery which contains a piece of soap made from the bodies of Jews burned at Auschwitz'. ${ }^{51}$

In 2000, filmmaker Velvel 'Lupu' Gutman, a Romanian Holocaust survivor living in California, traveled to his home country and shot a thirty-four-minute documentary entitled Monuments of Soap, released in $2001 .^{52}$ The dust jacket of 
the VHS cassette shows on its front the picture of a bar of soap with the inscription 'Rif / 0178'. On the reverse, the reader is informed that the movie 'details one of the Nazi's most horrific atrocities: The manufacture of soap from the bodies of innocents - murdered Jews'. The film not only shows six soap burial sites, but also contains a (black-and-white) insert from a film shot in the mid-1940s at the soap burial at Piatra Neamț.

The scene beginning at 7:52 minutes presents the soap monument, a quadratic column, at the cemetery of Buhuşi. It is remarkable because of the fact that Christian symbolism has been used here to illustrate Jewish suffering. In the upper part of the column, a bas-relief of yellow flames is blazing up from a bottom layer of coal. Above the flames a black rectangular metal grill is mounted, and on it the figure of a slim, naked pale human body, stretched out on their back. Under the left lower edge of the coals is the bas-relief of a soap cake with the inscription 'R.I.F'. The whole scene is reminiscent of traditional representations of the martyrdom of St. Lawrence in Christian religious art. ${ }^{53}$

\section{Political aspects of the Romanian soap burials}

The presence of prominent political, military and social activists, who did not miss the opportunity to take the floor, also turned the soap funerals into political events in Romania. In the country that was about to become a 'people's democracy', where the Communist Party was calling the shots, soap burials, like all public events, were increasingly subordinated to 'historical necessities' as understood within MarxistLeninist doctrine. In contrast, the religious aspect was fading in importance. This could be seen, for instance, in the tendency of media reports to dedicate further amounts of space to the dignitaries' speeches rather than the funeral ceremony itself. The Jewish press made no exception.

Spokesmen of all groups, Jewish or non-Jewish, called for 'sustain[ing], with all forces, the [new] democratic regime', and nearly all ceremonies culminated in vociferous calls for the punishment of the perpetrators. ${ }^{54}$ Neamul Evreesc, one of the oldest Romanian Jewish periodicals founded in 1907, wrote, for example, a report about a soap burial at Bucharest in June 1946:

The burial of the soap originating from the corpses of Hitlerite victims was also an occasion to declare our firm will to punish all criminals, all fascists, all Nazis, all Legionaries, all Antonescu followers - all, in the end, who murdered, who robbed, who oppressed, who made possible the governments of robbery, of terror and crime of the Legionaries and Antonescu followers. ${ }^{55}$

Though the author complained that punishment 'will neither resurrect those murdered, nor give back the stolen goods to the aggrieved', he concluded that it was absolutely necessary as 'an act of holy justice'. ${ }^{56}$

It should not be surprising, therefore, that voices were also heard demanding that RIF soap be introduced as incriminating evidence into the current trials of prominent war criminals. In May 1946, for example, Agerpress, the state-run 
Romanian press agency, reported that 'a quantity of fifty kilograms of toilet soap, manufactured from human fat, were discovered at the premises of merchant Lupu Nicolae' at Sibiu. ${ }^{57}$ In the same town, RIF shaving soap in private possession had been discovered some time earlier. ${ }^{58}$ The news inspired staff writer 'Ajax' from Neamul Evreesc to write an editorial, deploring, among other things, that 'at the recent Antonescu trial, these samples of the barbarities of the Axis and their comrades were not brought up' ${ }^{59}$

Politically and economically, Jews felt uneasy in post-war Romania. Antisemitism, which had been virulent already in pre-war times, had not vanished with the fall of the Antonescu regime and the retreat of its German ally. The new regime denied restitution of Jewish property (see the quotation in the second last paragraph) because it had already passed into the hands of the State or of other Romanians, and Jewish institutions became increasingly under pressure to bow to Communist ideology or risked being disbanded. Romanian Jewry saw only one way out: emigration to Eretz Yisrael, part of the British Mandate of Palestine until May 1948.

British interests in Arab countries, however, had drastically restricted Jewish immigration to Palestine. Therefore, at every soap funeral, calls were heard for 'Opening the gates'. Moritz Bacalu, for example, a prominent Zionist activist, said at the Dorohoi soap funeral: 'If England had opened Palestine's gates yet before 1940, these Jews turned into soap would have been far away, not in clay urns, but in their country, the Promised Land', ${ }^{60}$ and at the Timişoara soap funeral, Mauriți Mahler, a local Ichud leader, solemnly declared: 'We pledge in front of these remains that we will fight for building up a shelter of rest and labor for your brothers and children. A Jewish state in Palestine is the only reward rightfully deserved by your cruel sacrifice. ${ }^{61}$

\section{Western Jewry and the Romanian soap burials, 1945-46}

Western Jews who had read about Romanian soap burials about the turn of 1946 began to think about the role RIF soap might play in the Nuremberg trial of the major war criminals that started on 20 November 1945. In the 27 December 1945 issue of The Sentinel, for example, staff writer Milton Brown saw the soap's place on the bench:

I think those cakes were prematurely buried ... They should have been sent to Nuremberg and placed in the jury box. The dead should sit in the jury box at that trial ... I believe even the fat mouth of Goering would be stopped. ${ }^{62}$

Holocaust survivor Simon Wiesenthal, the future 'Nazi hunter', however, imagined RIF soap rather at the prosecutors' stand:

In Nuremberg, at the world's tribunal, millions of Nazis are also sitting in the dock. They knew it or did not know it, but they created the conditions under which everything that a sick brain devised became reality. And before the world's tribunal a little piece of soap is appearing - and accuses these millions! ${ }^{63}$ 


\section{Joachim Neander}

In both cases the authors obviously imagined something like a Jewish homunculus inside every cake of RIF soap, magically put inside by the Nazi soap-makers. It inspired them, in addition, to make far-reaching reflections on the German mindset. In the previously mentioned article in The Sentinel, for instance, Brown wrote:

If the Nazis were at a beer fest, gathered around the table, we can imagine how delighted they might be to take the soap of some bearded Jew ... I can see one German lifting his beer in one hand and the Jewish soap in the other, saying: 'Well, here is one Jew we kept from becoming another Einstein.' And another, in the same spirit, adding with uproarious laughter: 'Yes, and not another Jesus, either.' ${ }^{64}$

Likewise, Wiesenthal mused in the spring of 1946 in the Viennese Jewish weekly Der Neue Weg about a soap burial in Fălticeni: 'For the civilized world it is incomprehensible how joyfully the Nazis and their women in occupied Poland looked at this soap. In every bar they saw a Jew, magically put into it to prevent him from becoming a second Freud, Ehrlich, or Einstein. ${ }^{65}$ Tongue in cheek, he showed 'surprise that German thoroughness forgot to mention [on the wrapper] whether the fat was produced from children, from girls, or from young or old men' ${ }^{66}$ At the end of his reflections, he even struck a lyrical chord:

The burial of soap in a small Romanian town gives an impression of something unearthly. The enchanted woe encapsulated in this little object of daily use tears asunder the already petrified human heart of the twentieth century. In the atomic age, the return to the dark, medieval witch's kitchen makes an eerie impression! ${ }^{67}$

\section{Soap graves in Romania: no more in keeping with the times?}

The 'Jewish cemetery with the Soap Monument' in the home town of Nobel laureate Elie Wiesel is a must see for visitors of Sighetu Marmației. ${ }^{68}$ 'It contains two boxes filled with soap made by the Jews gassed at Auschwitz death camp', informs Trip Advisor, one of the most frequently visited Web portals for tourists and globetrotters. ${ }^{69}$ Originally, the soap tomb was marked by a stele with a Star of David and an inscription stating that 'this is the burial place of a quantity of soap cakes made from gassed bodies of Jewish victims in Auschwitz' ${ }^{70}$

Some time ago, however, the stele was replaced by a gray, low rectangular solid with a black memorial plaque on its upper surface. The new inscription is in Yiddish and was obviously copied from the far bigger, post-1989 Holocaust monument on Georghe Doja Street in the town centre, a few steps away from the Elie Wiesel Museum. It reads: 'To the eternal memory of the victims of the cruel Fascism in Auschwitz.' The word 'soap' no longer appears on the monument. The Web site of the state-run Romanian Tourist Office still suggests a visit to the cemetery, but does not mention the 'Soap Monument'. Times have changed. As the main attraction of the town, the Museum of Arrested Thought, dedicated to the victims of Communism, is recommended to the visitors. ${ }^{71}$ 
One can well understand that a memorial mentioning soap made from Auschwitz victims was no more acceptable in a public place visited year in, year out by thousands of foreign tourists after prominent Jewish Holocaust historians, backed by the authority of Yad Vashem, had publicly declared that no soap was made from Jewish flesh by the Germans. For the same reason, 'soap' vanished from the Holocaust monument erected in 1946 at Oradea in the courtyard of the Great Orthodox Synagogue, described as 'a large slab of stone next to the synagogue', and ' $[\mathrm{U}]$ nderneath it were buried some soap bars made from fat of Jews killed at Auschwitz' ${ }^{72}$ In the course of its modernisation, the monument obtained new 'soap-free' explanatory memorial plaques in four languages. Only after direct inquiry does the visitor hear that the soap bars are still lying underneath. ${ }^{73}$

The revision of history with the pickaxe, taking place here and at similar places in Romania, erases important documents telling what people were thinking in a bygone time and what, in their opinion, deserved immortalising in stone. Today's enlightened generation seem ashamed of the 'human soap' these monuments remember and want to forget about them. Two movements are converging here: a nationalist one that sees the monuments as eyesores, polluting Romanian soil, and a modernist one that appears ashamed, viewing them as relics from bygone times that make an unfavourable impression on foreign visitors.

The most radical position among the 'nationalists' is held by the Romanian Fatherland Union (Uniunea Vatra Românească), a right-wing organisation with a considerable number of supporters. Its leader, Ion Coja, demanded the following in an open letter from 3 October 2008, addressed to the President of the Republic and other prominent political personalities in the country:

1. the demolition of the foolish and ridiculous 'monuments of soap', which were proven to be totally mendacious;

2. an official, solemn apology before the Romanian people for these installations profaning Romanian soil! ${ }^{4}$

For a planned Holocaust memorial in Bucharest he expects 'that it will not be a hateful and stupid botch like the public memorials dedicated to the infamous soap!'75

The prevailing 'modernist' attitude in Romania towards the wealth of Holocaust monuments that remember 'soap' is ideally reflected in the report Historic Jewish Sites in Romania, issued in 2010 by the United States Commission for the Preservation of America's Heritage Abroad. They are simply ignored: 'There have been a small number of Holocaust monuments erected in Romania, mostly since the fall of the Ceausescu government in $1989^{\prime} .{ }^{76}$ From the older ones, only the Rădăuți monument was considered worth mentioning by the authors of the report. It is presented as 'a monument . . dedicated to those "who did not return"'.77 As everybody can convince themselves by consulting the Web, it is, however, dedicated to 'Soap R.I.F. / Reines Juden Fet[t] / Manufactured in German camps / Out of the martyrs' fat'. ${ }^{78}$ 


\section{No obituary yet for RIF soap}

From the beginning, scholars had problems with the soap allegedly made by the Germans from the murdered Jews. Those who looked into the matter immediately after the war in general took a sceptical stance. There had also already been critical voices in the ghettos. David Liwer remembered from the Będzin ghetto: 'We didn't know what the source of the [soap] rumor was. We discussed it at great length and reached the conclusion that there was no truth to it. ${ }^{79}$ Polish-Jewish historian Nachman Blumental, in an article for the journal Yiddishe Kultur, New York, published in 1959, brought it to the point: 'Neither the wave of rumors, nor quotations from books are proofs that the RIF soap was made from human fat. ${ }^{80}$

But opinionated survivors, who in most cases had heard the rumours only from fellow sufferers, kept the 'Jewish soap' story alive. Their accounts were widely published and also occasionally presented as evidence for the prosecution in trials of war criminals, but never cross-checked. ${ }^{81}$ Merging with Polish and Soviet tales about an alleged 'soap factory' detected in May 1945 at Danzig, they found their way into encyclopedias, textbooks and popular literature about the history of the Second World War. ${ }^{82}$ Anti-German sentiment in the public, as well as professionals' lack of interest in a critical examination of the Polish/Soviet soap allegations and the survivor accounts about 'Jewish soap' caused 'the erroneous assumption ... that soap was made from the bodies of murdered Jews ... [and] is still today widely held among scholars', as Yad Vashem historian Herbert Rosenkranz regretted in $1968 .{ }^{83}$

Since 1990, when the RIF soap legend was laid to rest by Yad Vashem ${ }^{84}$, only a fringe minority in academia have believed in the existence of soap made from Jews in the Holocaust. ${ }^{85}$ But outside of the History Department, in the sheer unlimited space of the World Wide Web, RIF soap is still alive and, in spite of its advanced age, hale and hearty. A Google search in January 2015 yielded approximately two million hits for the search inputs <jew+soap+holocaust $>$ in the nine languages dominant in Europe and the Americas. ${ }^{86}$ Rejuvenated by the increasing interest in Holocaust matters worldwide, and thanks to the new technologies of communication, RIF gathers around itself a growing community of the faithful. No matter how often in the real world RIF soap was buried, time for an obituary has not yet come. Not by a long shot.

\section{Notes}

1 A similar story was spread by Allied propaganda already twenty-five years earlier. See J. Neander, The German Corpse Factory: The Master Hoax of British Propaganda in the First World War (Saarbrücken, Saarland University Press, 2013).

2 I hope to be able to publish in the near future a monograph with the working title 'Soap, Lampshades and the Holocaust: A Study in Propaganda and MediaGenerated Folktales', where the 'Jewish soap' issue will be dealt with in greater detail. For a preliminary approach see J. Neander, 'Seife aus Judenfett: Zur 
Wirkungsgeschichte einer Zeitgenössischen Sage', FABULA: Journal of Folktale Studies, 46:3-4 (2005), 241-56.

3 See, for example, R. Hilberg, The Destruction of the European Jews (Chicago, Quadrangle Books, 1961), p. 614; H. Rosenkranz, 'RIF', Die Gemeinde, Vienna, 30 October 1968, p. 4; K. Feig, Hitler's Death Camps: The Sanity of Madness (New York \& London, Holmes \& Meier, 1981), p. 479; W. Laqueur, The Terrible Secret: Suppression of the Truth about Hitler's 'Final Solution' (Harmondsworth, Penguin Books, 1982), p. 82.

4 See, for example, 'Human Fat Wasn't Used by the Nazis, Israel's Holocaust Museum Says', The Globe and Mail, Toronto, 25 April 1990, p. A2; H. Orgel, 'Holocaust Scholar Denies Notion that Nazis Made Soap from Jews', Jewish Telegraphic Agency, 24 April 1990; B. Hutman, 'Nazis Never Made Human-fat Soap', The Jerusalem Post - International Edition, 24 April 1990, p. 2; in 1994 the United States Holocaust Memorial Museum sided with Yad Vashem. See M. Berenbaum, 'Dimensions of Genocide', in Y. Gutman \& M. Berenbaum (eds), Anatomy of the Auschwitz Death Camp (Bloomington, Indiana University Press, 1994), p. 80.

5 'Shall these Bones Live?' Address by Silvan Shalom, Deputy Prime Minister and Minister of Foreign Affairs of the State of Israel, delivered at the 28th Special Session of the United Nations General Assembly, 24 January 2005. URL: http:// mfa.gov.il/MFA/PressRoom/2005/Pages/Address by FM Shalom to the UN General Assembly Special Session 24-Jan-2005.aspx (accessed 25 July 2014).

6 M. Weber, 'Jewish Soap', The Journal of Historical Review, 11:2 (1991), 217-27, 223; for the 'anti-Revisionist' point of view see, for example, The Nizkor Project, Deceit \& Misrepresentation: The Techniques of Holocaust Denial. The Soap Allegations. URL: http://www.nizkor.org/features/denial-of-science/soap-01.html (accessed 14 November 2014).

7 As a first attempt, see J. Neander, "The Impact of the "Jewish Soap" and "Lampshades" Legends on Holocaust Remembrance', in C. Guenther \& B. GriechPolelle (eds), Trajectories of Memory: Intergenerational Representations of the Holocaust in History and the Arts (Newcastle-upon-Tyne, Cambridge Scholars Press, 2008), pp. 51-77.

8 According to Rabbi Steven Jacobs from Tuscaloosa, Alabama, 'respect for all parts of the human body' means: 'Nivul hamet (forbidding endless desecration of the body), halanat hamet (delaying the process of burial), and hana'at hamet (gaining benefit from the dead, i.e. use of the limbs for purposes other than burial) are all relevant Judaic concepts'. E-mail correspondence with the author, 6 February 2013.

9 'CCAR Responsa no. 170: The Burial of Human Organs', May 1988. URL: http:// ccarnet.org/responsa/narr-281-282/ (accessed 4 February 2013). Thanks to Rabbi Victor S. Appell, Union for Reform Judaism, New York, who provided me with this link.

10 'German Soap Made from Bodies of Jews Distributed to Jewish Inmates of UNRRA Camps', Jewish Telegraphic Agency, 26 November 1946.

11 'Brooklyn, NY - Holocaust (RIF) Soap Handed to Misaskim for Burial', Vos Iz 


\section{Joachim Neander}

Neias? The Voice of the Orthodox Jewish Community, New York, 25 January 2011. The article contains a brilliant picture of a cake of RIF soap. URL: http://www. vosizneias.com/74326/2011/01/25/brooklyn-ny-holocaust-rif-soap-handed-tomisaskim-for-burial/ (accessed 4 February 2013).

12 'Nazi Soap Sent to Misaskim', COLLIVE - Chabad Lubavitch Community News Service, 1 March 2011. URL: http://www.collive.com/show_news. rtx?id=13283\&alias=nazi-soap-sent-to-misaskim (accessed 4 February 2013).

13 Repeated requests sent to Misaskim by the author remained unanswered.

14 H. R. Diner, We Remember with Reverence and Love: American Jews and the Myth of the Silence after the Holocaust, 1945-1962 (New York \& London, New York University Press, 2009), passim.

15 This paragraph relies on anthropological concepts of the treatment of the dead body as discussed, for example in F. Stepputat, 'Governing the Dead? Theoretical Approaches', in F. Stepputat (ed.), Governing the Dead: Sovereignty and the Politics of Dead Bodies (Manchester, Manchester University Press, 2014).

16 Aliyah is the word used by Jews for immigration to Eretz Yisrael. The word literally means 'ascent', as the immigrant had to walk uphill to reach Jerusalem from the seashore.

17 This is taken from a photograph of the memorial. URL: http://www.jewishcuba. org/mar2.html (accessed 30 August 2014).

18 'Cuban Jews Hold Memorial Meeting for 6,000,000 Jewish Marters [sic] in Europe', Jewish Telegraphic Agency, 17 March 1947.

19 Diner, We Remember, p. 41; the monument was erected by the First Zbarazer Relief Society. Inscriptions are in Hebrew. A paragraph reads, in translation: 'Here lies soap, made by the German mass murderers, from the bodies of our brethren. May their souls rest in eternal peace', taken from the picture online. URL: http://www. museumoffamilyhistory.com/hm-zbarazh-bd.htm (accessed 30 August 2014).

20 H. Gutkowski, Erase una Vez ... Sefarad. Los Sefaradíes del Mediterráneo. Su história - Su Cultura. 1880-1945 - Testimonios (Buenos Aires, Lumen, 1999), pp. 152-3. Note that all the article's translations from foreign languages, as well as transcriptions of Yiddish texts, are the author's own.

21 R. DiAntonio, 'Yiddishkeit Tradition in the Contemporary Brazilian Narrative', in R. DiAntonio \& N. Glickman (eds), Tradition and Innovation: Reflections on Latin American Jewish Writing (Albany, State University of New York Press, 1993), pp. 45-60, 49.

22 Z. Ghivelder, As Seis Pontas da Estrela (Rio de Janeiro, Bloch, 1969), p. 133.

23 Only a few examples will be given here: 'Um Enterro Original. Barras de Sabão Feito com Gordura Humana Serão Inumadas, Simbólicamente, no Cemiterio de Vila Rosali', Diario de Noticias, Rio de Janeiro, 27 September 1947, p. 1; 'Rior Yishuv vet Simbolish Brengen tzu Kvure Yidishe Korbones fun Natzizm. Kumendikn Zentik vet Ba'erdikt 'Yidishe Zeyf Oyfn Besoylem fun "Vila Rosali"', Nossa Voz - Undzer Shtime, São Paulo, 9 October 1947, p. 2; 'Será Sepultada Hoje a Gordura Humana', Diario Carioca, Rio de Janeiro, 12 October 1947, p. 1; 'Milhares De Pessoas No Entêrro Simbólico Das Vítimas Dos Nazistas', Tribuna Popular, Rio de Janeiro, 14 October 1947, p. 8. 
24 O Cruzeiro has been compared to LIFE in the United States.

25 David Nasser, 'Num Cemitério do Rio - Entêrro de Sabão Humano', O Cruzeiro, 1 November 1947, pp. 9-12. Thanks to Davis Taublib, Rio de Janeiro, who provided me with a copy.

26 L. Maklouf Carvalho, Cobras Criadas: David Nasser e O Cruzeiro (São Paulo, Editora SENAC, 2001), p. 191.

27 DiAntonio, 'Yiddishkeit Tradition', p. 49.

28 Gutkowski, Erase una Vez, p. 153. The author gave, however, an erroneous number of soap bars buried $(3,000)$.

29 Ghivelder, As Seis Pontas, p. 133.

30 Advertisements in Nossa Voz - Undzere Shtime, São Paulo, 17 March 1949, p. 7 and 24 March 1949, p. 8.

31 '1947 “Enterro do Sabão” em Vila Rosali'. URL: http://www.youtube.com/ watch? $\mathrm{v}=9 \mathrm{uHbGWNBw6o}$ (accessed 9 November 2012).

32 'Protokol Funim Akt Beym Leygn Dem Grundshteyn far di Martire-Kurbanot Funim Hitler Rezhim Oyfn Beyt Hakhayim', in 'Vila Rosali' welkhe kumt far sontag 24 Elul התש"ט. Archives of the Chevra Kadisha of Rio de Janeiro, no date, no signature, handwritten slip of paper. Thanks to Davis Taublib in Rio de Janeiro who provided me with a copy.

33 Some examples: 'Noticiario - Rio de Janeiro. Monumento em Memoria das Vitimas do Nazismo', Nossa Voz - Undzer Shtime, São Paulo, 15 September 1949, p. 1; 'Perpetuando a Memória dos Judeus Sacrificados Pelo Nazismo. O Lançamento da Pedra Fundamental do Monumento Denominado "Reduto dos Mártires"', A Noite, Rio de Janeiro, 17 September 1949, p. 7; for a long article with a picture of the projected monument see 'Comovente Homenagem no Rio, às Vítimas do Nazismo', A Noite, Rio de Janeiro, 19 September 1949, p. 12; for a picture showing ten distinguished gentlemen looking at the foundation stone see 'Grundshteyn Fun Monument Oyf Ba'erdikt "Yudenzeyf”, Nossa Voz - Undzer Shtime, São Paolo, 22 September 1949, p. 1.

34 I. Blajberg, 'Dia Internacional in Memoriam das Vítimas do Holocausto', 27 January 2006. URL: http://www.israel3.com/article-print-832.html (accessed 30 July 2006).

35 Between 1918 and 1945, Romania's borders - and also, as a result, geographical names in the region - changed several times. In this article, 'Romania' is understood as the State within its post- 1945 borders, and geographical names (except 'Bucharest') will be used in the present Romanian spelling.

36 S. Wiesenthal, 'RIF', Der Neue Weg, Vienna, no. 17/18, 1946, p. 4.

37 “"Funeral" Held for Soap Made from Fat of Jews', The American Jewish Outlook, Pittsburgh, vol. 25, no. 19, 11 April 1947, p. 3; see also item no. 1812/45 of the Yad Vashem photo archives collection, caption 'Romania, Soap Collected by the Jewish Community and Brought for Burial'.

38 Quoted in F. Stan, 'Evreii din Constanța (III)', Revista TOMIS, Constanța, vol. 43, no. 456, March 2008, pp. 65-8, 68.

39 'Ştirii Interne', Viața Evreească, Bucharest, vol. 2, no. 82, 23 March 1946, p. 2.

40 Marius Mircu (pen-name of Israel Marcus): 'R.J.F. (Rein Jüdisches Fett)', Unirea, 
Bucharest, vol. 1, no. 4, November 1945, pp. 1-2, 2. The article was reprinted in M. Mircu, Pogromurile din Basarabia şi Alte Câteva Întâmplări: Contribuții la Istoria Încercării de Exterminare a Evreilor (Bucharest, Editora Glob, 1947), pp. 72-3.

41 Ibid.

42 Ibid.

$43 \mathrm{Ibid}$; the Theatergebäude was used by the SS as a warehouse. 'Several cauldrons, tubs, had been installed on the first floor. There pieces of soap recovered from the baggage of the victims of extermination were boiled up again. After mixing, the mass was left to cool down, cut to bars and dried.' Biuletyn Centrum Edukacyjnego Państwowego Muzeum Auschwitz-Birkenau w Oświęcimiu, April-June 2004.

44 'Most of the funeral ceremonies were attended by thousands of people, including army representatives'. "Funeral” Held for Soap Made From Fat of Jews', The American Jewish Outlook, Pittsburgh, vol. 25, no. 19, 11 April 1947, p. 3; see also the mostly very detailed reports in the Romanian Jewish press, mentioned previously and in the following paragraphs, as well as the voice-over in the film Monuments of Soap by Velvel Gutman, commenting on the soap burial at Piatra Neamț from 6:54 to 7:06 minutes.

45 Today this is Vrancea County.

46 ANDJ Vrancea, Fond Prefectura Judelețului Vrancea, dosar 54/1946, f. 20. Thanks to Viorel Achim in Bucharest who provided me with a copy.

47 Photo taken by Viorel Achim, Bucharest, in the spring of 2009, now in the author's collection.

48 'News Brief, Jewish Telegraphic Agency, 5 August 1947; 'Rumanian Jews Protest: Burial of Human Soap', The Jewish Chronicle: The Organ of British Jewry, London, no. 3,998, 23 November 1947, p. 1. Together with the soap, 'desecrated Sifrei Torah' were buried.

49 'Relatives Mourning over Soap Used in Ceremony', Bucharest, 4 August 1947'. URL: http://www.corbisimages.com/stock-photo/rights-managed/U1069555INP/ relatives-mourning-over-soap-used-in-ceremony (accessed 30 January 2013).

50 'Soap Made from Jew Bodies by Germans', Townsville Daily Bulletin, Townsville, Australia, 15 August 1947, p. 1. Without giving a date and localised only as 'Romania', the picture also appears in the Yad Vashem photo archives, no. 1812/64 (accessed 30 March 2013).

51 'Rumanian Jews Commemorate 25th Anniversary of Nazi Deportations', Jewish Telegraphic Agency, 5 June 1969.

52 G. Wening, 'Lupu's Lens: The 75-year-old Filmmaker Educates Teens about AntiSemetism [sic]', The Jewish Journal of Greater Los Angeles, 28 December 2001. The movie has been uploaded on the Web. URL: http://blip.tv/file/2973635 (accessed 15 December 2010). Thanks to Velvel Gutman who provided me with a VHS copy of his film.

53 According to the legend, St. Lawrence was burnt to death on a grill. Eightyone examples of scenes depicting the martyr's death are at the web site of the Fondazione Federico Zeri of the University of Bologna, Italy. URL: http:// 
fe.fondazionezeri.unibo.it/catalogo/ (accessed 19 December 2010): search 'Titolo/ Soggetto/' for 'martirio di san lorenzo'.

54 'Inhumarea săpunuul [sic] R.I.F. la Bacău', Viața Evreească, Bucharest, vol. 2, no. 74, 26 January 1946, p. 3.

55 R. Marian, 'Inhumarea Săpunului', Neamul Evreesc, Bucharest, vol. 40, no. 7, 25 June 1946, p. 3. 'Legionaries' refers to the 'Iron Guard', a fascist organisation banned by Antonescu, but very active in persecuting Jews.

56 Ibid.

57 'Săpun din Grăsimi Evreești Descoperit la Sibiu', Viața Evreească, Bucharest, vol. 2, no. 91, 26 May 1946, p. 4.

58 Ibid.

59 “'R.I.F”: Săpun Curat Evreesc', Neamul Evreesc, Bucharest, vol. 39, no. 9, 20 June 1946, p. 3.

60 'Morminte Fara Morți', Neamul Evreesc, Bucharest, vol. 39, no. 3, 19 February 1946, p. 4.

61 “"Viața Evreească” în Provincje - Timişoara', Viața Evreească, Bucharest, vol. 2, no. 34, 6 April 1946, p. 3.

62 M. Brown, 'A Cake of Soap: With the Solemnity of a Regular Funeral, a Cake of Soap was Laid to Rest', The Sentinel - Devoted to Unity in Jewish Life, Chicago, vol. 140, no. 13, 27 December 1945, p. 13.

63 Ing[enieur] Wiesenth[al], 'RIF', Der Neue Weg, Vienna, no. 17/18, 1946, p. 4-5, 5.

64 Brown, 'A Cake of Soap'.

65 Wiesenthal, 'RIF', p. 4.

66 Ibid., p. 5. See also Brown, 'A Cake of Soap', to which, up to the wording, Wiesenthal's text shows striking similarities.

67 Wiesenthal, 'RIF', p. 5.

68 See the Romania Jewish Tours website. URL: http://www.romaniajewishtours. com/jewish-treasures-of-romania-the-grand-tour/ (accessed 18 December 2010).

69 Trip Advisor, 'Sighetu Marmatiei: Things to Do'. URL: http://www.tripadvisor.ie/ Travel-g608955-s4/Sighetu-Marmatiei:Romania:Things.To.Do.html (accessed 19 December 2010).

70 This is according to 'an affidavit from George Mezei, a former Sighet police chief. J. Rolnick, 'Slippery History: The Soap “Myth”', Moment, Washington, DC, 30 June 2000, p. 58; similarly, see H. Kamm, 'Elie Wiesel's Hometown: Few Traces of Past', New York Times, 9 December 1986, p. A9: 'cakes of soap ... made of the remains of the victims of the gas chambers and furnaces of Auschwitz'.

71 See the Romania Tourism website. URL: http://www.romaniatourism.com/ sighetu-marmatiei.html (accessed 19 December 2010).

72 L. Gapay, 'Scarred Remains: A Son Agonizes over his Father's Torturous Role in the Holocaust in Hungary', Baltimore Jewish Times, 18 March 1994, p. 64.

73 See the voice-over in Monuments of Soap, from 15:09 to 15:26 minutes.

74 I. Coja, 'Apel la Memorial' on personal website. URL: http://www.ioncoja. ro/2008/10/apel-la-memorial/ (accessed 27 December 2010). Emphasis and exclamation marks in the original.

75 Ibid. 


\section{Joachim Neander}

76 'Historic Jewish sites in Romania', Washington, DC, United States Commission for the Preservation of America's Heritage Abroad, 2010, p. 34.

77 Ibid.

78 See pictures online. URL: http://www.shtetlinks.jewishgen.org/radauti/ lindertrip05.htm accessed (30 August 2014); http://www.hpgrumpe.de/ rumaenien/radautz2/radautz2.html (30 August 2014). The words 'Reines Juden Fet' appear in German.

79 D. Liwer, 'Bedzin in Her Destruction: Excerpts from "City of the Dead", Tel Aviv, Teverski, 5707 [1946/47] (L. Ackerfeld trans.). URL: http://www.jewishgen.org/ Yizkor/bedzin/bed342.html (accessed 22 October 2006).

80 Quoted, in Hebrew translation, in S. Shner-Neshamit, גם למתים לא הניחו, Lochamei Hagetaot, Israel, 1998, p. 5.

81 See some early press reports in which soap-making from Jews is mentioned, apart from Wiesenthal's in Der Neue Weg: 'Editorial: Crimes Against Jews Must be Punished', The Canadian Jewish Chronicle, 2 February 1945, p. 6; 'Rabbi's Wife and Child Freed from Horror Prison', The Pittsburgh Press, 8 May 1945, p. 15; 'What Kind of Soap Will They Make Out of Me', The Canadian Jewish Chronicle, 17 August 1945, p. 9; 'Jewish Immigrants Forced To Seek Special Permits', The Canadian Jewish Chronicle, 5 July 1946, p. 8.

82 See J. Neander, 'The Danzig Soap Case: Facts and Legends around "Professor Spanner" and the Danzig Anatomic Institute 1944-1945', German Studies Review, 29:1 (2006), 63-86.

83 Rosenkranz, 'RIF', p. 14.

84 See endnote 4. Even those who still believe in the 'Experimental human soap factory' at Danzig were reminded by Yehuda Bauer that 'it did not involve Jewish bodies'; letter to The Jewish Standard, 9 January 1991; similarly R. Hilberg, 'Holocaust Scholar Denies Notion that Nazis Made Soap from Jews', Jewish Telegraphic Agency, 25 April 1990.

85 See, for example, B. Shallcross, The Holocaust Object in Polish and Polish-Jewish Culture (Bloomington \& Indianapolis, Indiana University Press, 2011), chapter 3.

86 Italian: 741,000; German: 387,000; Hebrew: 320,000; English: 160,000; Polish: 137,000; Russian: 42,900; Spanish: 29,400; French: 26,500; Portuguese: 13,500. 'Believers' and 'deniers' approximately balance each other. 